\title{
Unusual Circumstances of Death due to Domestic Animals
}

\author{
Cristian Gherman*2 and Gheorghe Lazar ${ }^{1}$ \\ ${ }^{1}$ Resident Doctor in Forensic Medicine, Institute of Legal Medicine Cluj-Napoca, Romania \\ ${ }^{2}$ Senior Doctor in Forensic Medicine, Institute of Legal Medicine Cluj-Napoca, Romania
}

Submission: January 26, 2018; Published: February 02, 2018

*Corresponding author: Cristian Gherman, Resident Doctor in Forensic Medicine, Institute of Legal Medicine Cluj-Napoca, Romania,

Email: gcpnad2002@yahoo.com

\section{Case Report}

When identified in a corpse, traumatic lesions produced by animals can be classified both in the category of postmortem destructive processes and also among traumatic lesions produced by biological agents, some with life-threatening potential, depending on the time of occurrence, respective prior or after the moment of death [1]. A correct differential diagnosis is essential for this matter and it is based macroscopically by the presence of blood infiltrates in the borders of the wound, and certified microscopically by the observation of the ruptured small blood vessel with blood infiltrates in the vicinity [2]. Literature reveals an overall low percentage of cases where the death was produced by biological agents out of all causes [3]. Traditionally, when the topic is violent death due to animals, the first though is to assimilate them with fatal lesions induced by wild animals [4]. However, surprisingly, there are very rare cases, understudied, in which the death is due to a traumatic lesion inflicted by domestic animals.

In order to illustrate the previous statements, we chose to present the case of a 46-years old male, found dead in his own backyard. The patient was on illness retirement due to multiple cardiovascular diseases such as declarative cardiomyopathy and pulmonary hypertension-all documented in his PMH. Data collected from the police investigation team revealed that this person used to breed pigs in his household. On daily basis, he fed them and cleaned their stable. The crime scene investigation reveals a male body with multiple bite wounds most of them at the cranial and facial level, found in the stable area. Also, a large pig with blood around his mouth was identified at the scene. Forensic autopsy was performed in this case. Also, histopathological and toxicological analyses were performed. At the necropsy, the external examination revealed multiple bitten wound at cranio-facial level, with loss of soft tissue and margins being irregular and blood-infiltrated (Figure 1).
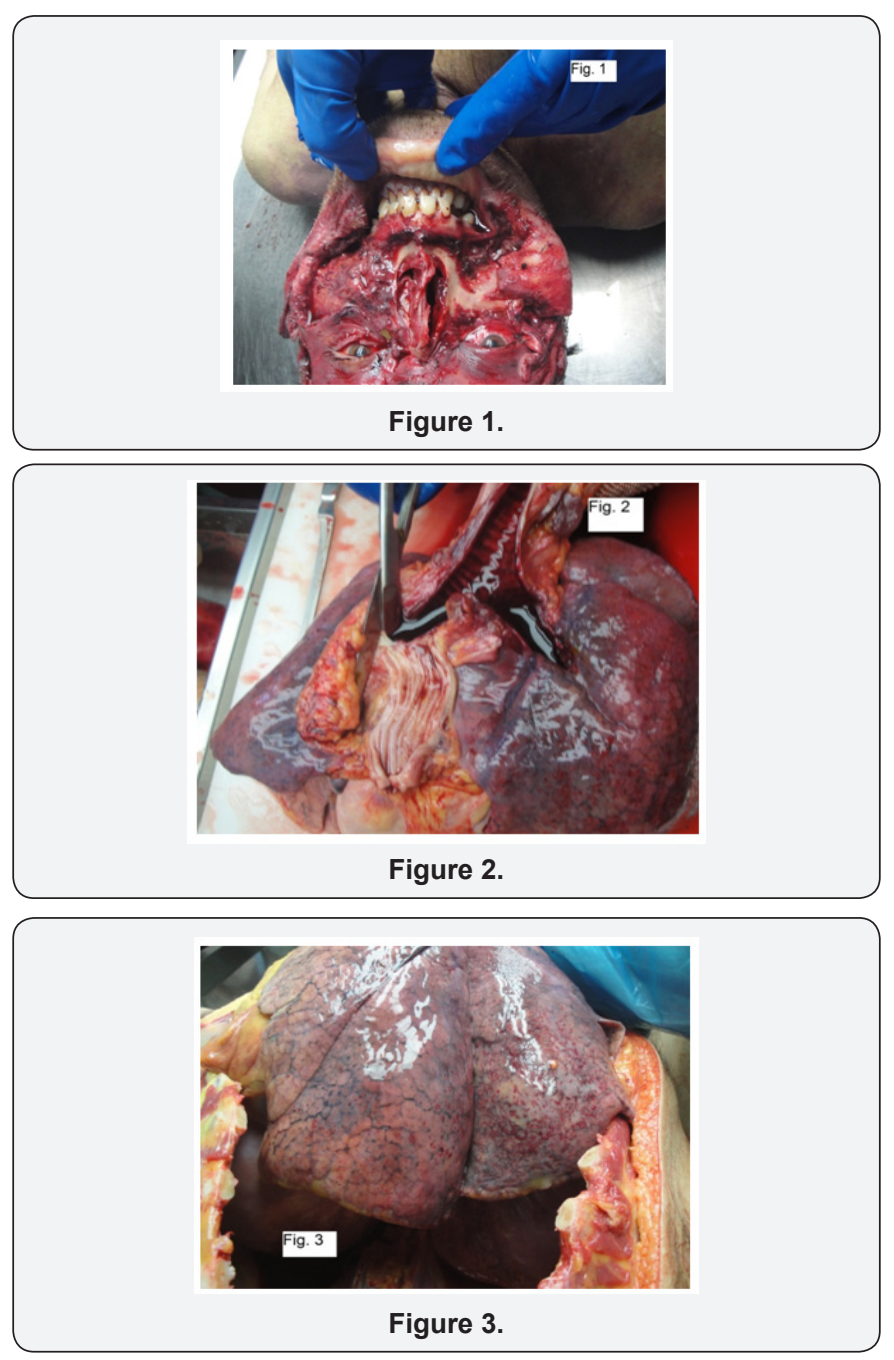

The internal examination underlined blood aspirate at tracheal level, and also in the entire respiratory tract, consecutive 
to the massive bleeding bitten wounds at the cranial extremity (Figure 2). Also, a very well-represented petechial hemorrhaging due to asphyxia was identified at the visceral pleura level along with intense acute pulmonary emphysema areas (Figure 3). Histopathological examination confirmed the vital character of the soft tissues lesions and certified blood aspiration at the lung level. Toxicological exam ruled out the possibility of a fall prior to death due to alcohol or drugs. A depressed level or even a loss of consciousness due to cardiac syncope remained the only possible medical explanation. All the facts above led us to conclusion that the death was violent and was caused by mechanical asphyxia by total obstruction of upper and lower airways with blood aspirate consecutive to intense bleeding animal-produced bitten wounds at the craniofacial level.

By presenting a case conducted as a whole, starting from the crime scene investigation and up until the corroboration between the results of complementary analysis and the aspect revealed by the necropsy, our aim is to underline the importance of a correct diagnosis regarding the time of lesion occurrence, of a differential diagnosis performed with celerity and also the benefits of a correct conducted crime scene investigation in all cases of death that are suspected of being violent.

\section{References}

1. Fatteh A (1971) Distinction between antemortem and postmortem wounds: a study of elastic fibers in human skin. J Forensic Sci 16(3): 393-396.

2. Perper JA, Wecht CH (1980) Microscopic Diagnosis in Forensic Pathology. Springfield 2(2): 189.

3. Erikson R, Torssander J (2008) Social class and cause of death. European Journal of Public Health 18(5): 473-478.

4. Langley RL, Morrow WA (1997) Death resulting from animal attacks in the United States. Wilderness \& Environmental Medicine 8(1): 8-16.

This work is licensed under Creative Commons Attribution 4.0 License

DOI : 10.19080/JFSCI.2018.07.555713
Your next submission with Juniper Publishers will reach you the below assets

- Quality Editorial service

- Swift Peer Review

- Reprints availability

- E-prints Service

- Manuscript Podcast for convenient understanding

- Global attainment for your research

- Manuscript accessibility in different formats ( Pdf, E-pub, Full Text, Audio)

- Unceasing customer service

Track the below URL for one-step submission https://juniperpublishers.com/online-submission.php 